\title{
MEMPELAJARI MISTERI ILMU KHIDIR DALAM ERA MILLENIAL (Analisis Kontroversi Gus Dur Perspektif Ilmu Khidir)
}

\author{
Oleh: \\ Ahmad $^{1}$ \\ Email: ahjelly@gmail.com
}

\begin{abstract}
Calling Gus Dur's name must have crossed the Ulama ', Nation's Teachers, thinkers. However, the figure of Gus Dur cannot be separated from his thoughts which are often controversial and eccentric. One of them was Gus Dur's thought to revoke the Standing Regulations of the People's Consultative Assembly Number XXV in 1966 concerning the dissolution of the Indonesian Communist Party, the statement as a prohibited organization throughout the Republic of Indonesia for the Indonesian Communist Party and prohibition of any activities to disseminate or develop ideas or teachings communism / Marxism-Leninism. This thinking is not only controversy and eccentric, but also invites strong reactions from the people themselves, the scholars. In a different frame and context, the controversy that is similar to Gus Dur's thought ever happened and enshrined in the Qur'an, namely the story of the Prophet Khidr and Prophet Moses. In the horizon of thought, Gus Dur basically "just" explained the knowledge that was known and other people did not know it. Likewise, Prophet Khidir when 'giving lessons' to the Prophet Moses. Prophet Khidir 'only' explained what was known while the Prophet Moses did not know it.
\end{abstract}

Key words: Gus Dur controversy, Khidir science

\section{Pendahuluan}

Perjalanan dan sejarah sebuah tidak akan terlepas dari lika-liku, begitu pun dengan Indonesia. Lika-liku perjalangan dan sejarah bangsa Indonesia sangat panjang. Berada di kawasan Asia Tenggara, bangsa ini terdiri dari berbagai macam suku, agama, ras, bahasa, golongan serta

${ }^{1}$ Dosen Prodi Hukum Pidana Islam STAI Syaichona Moh. Cholil Bangkalan 
perbedaan lainnya. Namun, perbedaan-perbedaan disatukan dalam sebuah falsafah besar Bhineka Tunggal Ika².

Setelah Indonesia diproklamasikan, bangsa ini tidak dibentuk atas dasar negara agama, kesukuan, atau kerajaan dan etnis tertentu. Bangsa ini dibangun atas dasar penghargaan terhadap "darah daging" perbedaan dengan ideologi dasar berupa Pancasila, dan, - setidaknya- sampai saat ini Pancasila telah berhasil mempersatukan bangsa yang "darah dagingnya" telah tercipta berbeda-beda ini ${ }^{3}$.

Pada tahun 2019 ini, Indonesia akan menghadapi Pemilu 2019. Salah satu isu yang paling menyita perhatian adalah isu kebangkitan Partai Komunis Indonesia (PKI). PKI menjadi komoditas politik paling seru, kalau tidak dibilang paling menakutkan. Dalam sejarahnya, bangsa ini telah mengalami periode kelam bersama dengan komunis dan PKI. Ideologi komunis pernah menjangkiti sebagian dari warga republik ini. Hingga akhirnya meletus peristiwa pemberontakan PKI tahun 1965 yang menewaskan ribuan masyarakat yang tidak berdosa. Pemberontakan PKI inipun menimbulkan prahara 'pembalasan' terhadap pada pelaku

2 Bhineka Tunggal Ika merupakan falsafah yang digali dari pedoman hidup Bangsa Indonesia. Falsafah ini tertuang dalam Kitab Sutasoma gubahan Empu Tantular. Kutipan tersebut adalah Hyang Budha tan pahi Ciwa Raja Dewa, Rwangkadhatu Winurus Wara Budha Wicwa, Bhineka rakwa ring apan kena parwanosen, Mangka Yittna lawan Ciwatatwatunggal, Bhinneka Tunggal Ika tan hana dharma wangsa. Baca Prof. Dr. Kaelan MS. Pendidikan Pancasila. Yogyakarta: Paradigma. Cet X 2014. Hal 23. Dalam periode sebelum Indonesia merdeka, falsafah ini mengeruak dalam bentuk Sumpah Pemuda, yang dilatarbelakangi oleh kesadaran bersama atas senasib sepenanggunan untuk mempersatukan perbedaan dalam sebuah persatuan dalam simbol Bangsa dan bahasa Indonesia.

${ }_{3}$ Pancasila berasal dari kata panca yang berarti lima dan syila yang berarti batu sendi, pondasi, dan dasar. Secara harfiah Pancasila berarti peraturan tingkah laku yang baik. dalam ajaran Budha terdapat ajaran, Dasyasila (sepuluh pedoman), Saptasyila (tujuh sendi) dan Pancasyila (lima sendi). Sebagai pedoman hidup dalam Agama Budha, Pancasila terdiri dari panatipada (larangan membunuh), Dinna Dana (larangan mencuri), Kameshu Micchacara (larangan berzina) Musawada (larangan berdusta) dan Sura Meraya (larangan minuman). Selanjutnya, masuknya ajaran Islam, ajaran Pancasyila sedikit mengalami akulturasi dan berubah menjadi mo limo (lima larangan moral) yaitu mateni maling, madon, mabok dan main. Ajaran ini terus dipegang oleh Bangsa Indonesia, hingga akhirnya dintrodusir oleh Ir. Soekarno, Moh. Yamin dan Prof. Soepomo, dan akhirnya disahkan dalam Sidang BPUPKI. Baca Prof. Dr. Kaelan MS. Pendidikan Pancasila. Yogyakarta: Paradigma. Cet X 2014. Hal 18-39. 
pemberontakan itu sendiri. Pada akhirnya, upaya 'pembalasan' atas pemberotankan PKI inipun juga menimbulkan korban yang tidak sedikit. Atas nama pemberantasan PKI orang dengan mudah dihabisi dan dibunuh, hingga keluarlah TAP MPR No XXV Tahun 1966 tentang Pembubaran Partai Komunis Indonesia, pernyataan sebagai organisasi terlarang di seluruh wilayah Negara Republik Indonesia bagi partai komunis Indonesia dan larangan setiap kegiatan untuk menyebarkan atau mengembangkan paham atau ajaran komunisme/marxisme-leninisme.

Selama periode pemerintahan Soeharto, bisa dikatakan komunis dan PKI tidak pernah muncul ke permukaan. Namun, setelah masa reformasi, isu komunis dan PKI kembali menyeruak lagi. Salah satu yang kontroversi adalah pernyataan Presiden Indonesia ke 4, KH. Abdurrahman Wahid yang hendak mencabut TAP MPRS tersebut.

Menyebut nama KH. Abdurrahman Wahid atau yang lebih dikenal dengan Gus Dur berarti menyebut salah tokoh bangsa, ilmuwan, ulama' sekaligus negarawan yang pemikiran dan perbuatannya sering mendapat perhatian. Perhatian dan kepedulian orang terhadap sosok KH. Abdurrahman Wahid tidak terlepas dari berbagai sepak terjangnya. Sebagai negarawan, Gus Dur pernah menjabat sebagai Presiden RI yang ke 4, di tengah kondisi Indonesia mengalami reformasi. Sebagai ulama', Gus Dur telah diakui kealimannya, serta pernah menjabat sebagai Ketua PBNU selama dua periode. Sebagai ilmuwan dan pemikir, Gus Dur adalah salah satu tokoh dunia yang telah mewarnai pemikian Indonesia bahkan dunia terutama tentang kemanusiaan, toleransi, serta kebebasan dan demokrasi. Gus Dur adalah seorang seorang figur yang sederhana, bersahaja, humoris dan bahkan jenaka dengan berbagai macam guyonan dan joke-jokenya. Namun demikian, yang paling fenomenal dari cara pandang berpikir Gus Dur adalah cara berpikirnya yang berbeda dari kebanyakan orang, nyeleneh, kontroversi, absurd, tidak mudah dimengerti bahkan sembarangan dan misterius 4 .

Tulisan ini akan fokus pada pemikiran Gus Dur yang 'dianggap' kontroversial. Namun demikian, penulis tidak akan membahas semua

4 Greg Barton. Biografi Gus Dur The Autorized Biography Of Abdurrahman Wahid. Yogyakarta: LKiS. Cet VIII. 2008. Hal 21. 
kontroversi pemikiran Gus Dur. Penulis hanya akan menfokuskan tulisan ini pada kontroversi keinginan Gus Dur untuk mencabut TAP MPR tentang pelarangan PKI.

Saat masih menjabat sebagai presiden, Gus Dur mengeluarkan pernyataan yang kontroversial. Gus Dur akan mencabut TAP MPR No XXV Tahun 1966 tentang Pembubaran Partai Komunis Indonesia, pernyataan sebagai organisasi terlarang di seluruh wilayah Negara Kesatuan Republik Indonesia bagi Partai Komunis Indonesia dan larangan setiap kegiatan untuk menyebarkan atau mengembangkan paham atau ajaran komunisme/marxisme-leninisme.

Isi lengkap dari TAP MPR no XXV tahun 1966 adalah sebagai berikut. ${ }^{5}$

\section{Pasal 1}

Menerima baik dan menguatkan kebijaksanaan Presiden/Panglima Tertinggi Angkatan Bersenjata Republik Indonesia/Pemimpin Besar Revolusi/Mandataris Majelis Permusyawaratan Rakyat Sementara, berupa pembubaran Partai Komunis Indonesia, termasuk semua bagian organisasinya dari tingkat pusat sampai ke daerah beserta semua organisasi yang seazas/berlindung/bernaung di bawahnya dan pernyataan sebagai organisasi terlarang di seluruh wilayah kekuasaan Negara Republik Indonesia bagi Partai Komunis Indonesia, yang dituangkan dalam keputusan tanggal 12 Maret 1966 No 1/3/1966, dan meningkatkan kebijaksanaan tersebut di atas menjadi Ketetapan MPRS.

\section{Pasal 2}

Setiap kegiatan di Indonesia untuk menyebarkan atau mengembangkan paham atau ajaran Komunisme/Marxisme-Leninisme dalam segala bentuk dan manifestasinya, dan penggunaan segala macam aparatur serta media bagi penyebaran atau pengembangan paham atau ajaran tersebut, dilarang.

5 TAP MPR No XXV Tahun 1966 tentang Pembubaran Partai Komunis Indonesia, pernyataan sebagai organisasi terlarang di seluruh wilayah Negara Republik Indonesia bagi Partai Komunis Indonesia dan larangan setiap kegiatan untuk menyebarkan atau mengembangkan faham atau ajaran Komunisme/MarxismeLeninisme. 


\section{Pasal 3}

Khususnya mengenai kegiatan mempelajari secara ilmiah, seperti pada universitas-universitas, paham Komunisme/Marxisme-Leninisme dalam rangka mengamankan Pancasila, dapat dilakukan secara terpimpin, dengan ketentuan, bahwa pemerintah dan DPR-GR diharuskan mengadakan perundang-undangan untuk pengamanan

Terlepas dari kontroversi dan segala intrik yang melingkupinya, bagaimanapun, komunis melalui PKI di Indonesia telah membuat sejarah kelam, trauma dan menumpahkan banyak darah rakyat Indonesia. Sontak pernyataan ini mengundang reaksi keras dari berbagai macam kalangan. Pernyataan ini tidak hanya dianggap kontroversi dan nyleneh, Gus Dur dianggap telah mencederai sejarah bangsa Indonesia melalui PKI. Pada akhirnya, kontroversi keinginan Gus Dur mencabut TAP MPR ini tidak menjadi kenyataan.

\section{Sepak Terjang dan Pemikiran Gus Dur}

Mengenang sosok Gus Dur tidak bisa terlepas dari kontroversi dan aneh tersebut. Bagaimana tidak, kontroversi dan keanehan sepak terjang Gus Dur memang telah melekat dalam karakter dan kepribadiannya. Banyak pemikiran dan perbuatan Gus Dur yang dianggap tidak biasa, bukan hanya oleh orang luar, namun di kalangan pesantren dan ulama'pun, Gus Dur tetaplah seorang yang aneh. Wajar, jika tokoh nasional sekelas Kiai As'ad Situbondopun sempat terlibat friksi dengan Gus Dur6.

Menelisik keanehan dan kontroversi Gus Dur, barangkali sudah akan terlihat sejak Gus Dur dilahirkan. Terdapat perbedaan tentang tanggal lahir Gus Dur. Ketika Gus Dur menjadi presiden, ulang tahun Gus Dur selalu dirayakan 4 Agustus 1940. Namun, pengakuan Gus Dur sendiri, beliau

\footnotetext{
${ }^{6}$ Saat Gus Dur menjabat sebagai Ketua PBNU, Kiai As'ad diketahui pernah menyatakana mufaroqoh (keluar) dari barisan kepengurusan PBNU pimpinan Gus Dur. Sikap tegas Kiai As'ad ini dilatarbelakangi oleh sepak terjang Gus Dur yang memang nyeleneh, kontroversi, dan sulit diatur. Dalam kaca mata Kiai As'ad, Gus Dur diibaratkan sebagai imam sholat, tatkala imam sholatnya batal, maka makmum wajib untuk mufaroqoh (keluar dari sholat) dan mendirikan sholat sendiri.
} 
lahir pada tanggal 4 bulan kedelapan kalender hijriah pada tahun 1940, dengan demikian hari kelahiran Gus Dur adalah 7 September $1940^{7}$.

Gus Dur kecil diasuh dalam lingkungan yang kompleks. Sebagai cucu dari KH. Hasyim Asy'ari dari jalur ayah (KH. Wahid Hasyim, ayah Gus Dur) dan KH. Bisri Syamsuri dari jalur ibu (Sholihah, ibunda Gus Dur) Gus Dur diasuh dalam pendidikan yang kental dengan nuasa pesantren yang tradisional. Gus Dur kecil sudah bergumul dengan pemahaman alQur'an dengan penguasaan gramatikal Bahasa Arab yang kuat. Dari satu pesantren Gus Dur pindah ke pesantren lainnya. Kitab-kitab standar yang diajarkan di pesantren telah dikuasainya, bahkan puisi-puisi berbahasa Arab telah habis dilahap Gus Dur.

Dari sini, lalu bakat Gus Dur dalam bindang penguasaan agama telah terlibat cemerlang. Saat berada di pesantren-pesantren ini pula, ketertarikan Gus Dur atas sufisme dan 'alam lain' juga muncul. Saat berpetualang dari satu pesantren ke pesantren lainnya, Gus Dur sering mengunjungi makam-makam keramat, hingga pernah menjalani 'tirakat' berjalan kaki dari Jombang hingga pantai selatan, yang berjarak sekitar 100 $\mathrm{km}$.

Di sisi lain, sang Ayah yang menjabat sebagai Menteri Agama mempunyai pemikiran keislaman progresif dan modern. Saat menjadi Menteri Agama, Gus Dur mengikuti ayahnya tinggal di Jakarta, sementara ibu dan adik-adiknya tinggal di Jombang. Sebagai putra dari pejabat negara, Gus Dur kecil telah melihat sang Ayah bergaul dengan berbagai macam golongan dan latar belakang. Gus Dur sering membukakan pintu pada tamu yang datang malam-malam untuk berdiskusi dengan Ayahnya, yang tamu ini sering meminta dipanggil dengan Paman Husein, yang tiada lain adalah Tan Malaka, seorang pimpinan dan pemikir komunis berpengaruh pada masa itu. Tak heran, Gus Kecil telah mampu berbahasa Ingris, Belanda, dan Perancis.

Setelah menamatkan pendidikannya di Indonesia, Gus Dur lalu berpetualang melanjutkan sekolah ke luar negeri, belajar ke Universitas alAzhar Mesir atas beasiswa yang diterima. Perpaduan tradisional dan

${ }^{7}$ Ibid. Greg Berton. Hal 25. 
modern inilah telah menempa Gus Dur kecil menjadi seorang yang pemikir yang mempunyai pandangan luas.

\section{Sejak Terjang dan Ilmu (Kontroversi) Nabi Khidir}

Tidak dapat dipungkiri bahwa sosok Nabi Khidir adalah sosok misterius. Kemisteriusan Nabi Khidir telah muncul saat mengenal nasab Nabi Khidir sesunggunya. Ada yang mengatakan bahwa Nabi Khidir adalah putra dari Nabi Adam. Ada pula yang mengatakan Nabi Khidir adalah putra Qobil bin Adam. Ada pula yang mengatakan Nabi Khidir adalah Balyan bin Malkan bin Faligh bin Syalikh bin 'Amir bin Arfakhsyadz bin Sam bin Nuh, dan banyak lagi versi sosok Nabi Khidir8. Sementara panggilan Khidir (khidir atau khodlru خضر yang berarti hijau) dinisbatkan kepada tanah yang (rumputnya akan) berubah menjadi hijau, saat Nabi Khidir mendudukinya9.

Salah satu perdebatan panjang tentang sosok Nabi Khidir adalah keberadaannya yang masih misterius, apakah Nabi Khidir masih hidup ataukah sudah wafat. Nabi Khidir disebut-sebut sebagai salah satu Nabi dari 3 Nabi yang diberi keabadian umur panjang hingga hari kiamat.

Salah satu bukti yang menyatakan bahwa Nabi Khidir hidup abadi adalah kisah pertemuan dengan Nabi Muhammad. Kisah pertemuan Nabi Khidir dan Baginda Nabi Muhammad tercatat dalam sebuah hadits

$$
\begin{aligned}
& \text { روى ابن عدي في الكامل ، من طريق عبد الله بن نافع عن كثير بن عبد الله بن عمرو بن } \\
& \text { عوف ، عن أبيه عن جده : ' أن رسول الله - - كان في المسجد ، فسمع كلاما من ورائه ، } \\
& \text { فإذا هو [ بقائل ] يقول : اللهم أعني على ما ينجيني مما خوفتني . فقال رسول الله - - } \\
& \text { حين سمع ذلك : ' ألا تضم إليها أختها ' . فقال الرجل : ' اللهم ارزقني شوق الصالحين ، }
\end{aligned}
$$

8 Perbedaan pendapat tentang nasab Nabi Khidir terjadi hingga sepuluh pendapat.

9 Syihabuddin Ibn Hajar al-Asqolani. Az-Zahr al-Nadhor fi Akhbari al-Khidr. Maktabah Syamilah. Juz 1 hal 64. 


$$
\begin{aligned}
& \text { إلى ما شوقتهم إليه فقال النبي - - لأنس بن مالك [ وكان معه ] : اذهب يا أنس ! فقل } \\
& \text { له : يقول لك رسول الله - - : استغفر لي . فجاءه أنس ، فبلغه ; فقال الرجل : يا أنس } \\
& \text { ! أنت رسول رسول الله - - الي ؟ فرجع فاستثبته ـ فقال له النبي - - : قل له : نعم ! } \\
& \text { فقال له : اذهب ، فقل له : ' إن الله فضلك على الأنبياء مثل ما فضل به رمضان على } \\
& \text { الشهور ; وفضل أمتك على الأمم مثل ما فضل يوم الجمعة ، على سائر الأيام [ فذهبوا } \\
& \text { ينظرون ] ، فإذا هو : الخضر [ عليه السلام ] }
\end{aligned}
$$

"Pada suatu ketika Nabi sedang berada di dalam masjid. Nabi Muhammad mendengar ada seseorang yang bercakap-cakap seraya berdoa "Ya Allah, berilah saya pertolongan dengan segala hal yang bisa menyelematkanku dari apa-apa yang Engkau takutkan padaku". Setelah mendengar doa yang dipanjatkan seseorang yang ada di luar masjid, Nabi Muhammad bersabda: "Tidakkah engkau bertemu dengan saudaranya"? Lalu orang asing tersebut berkata seraya berdoa "Ya Allah berilah saya rejeki kerinduan pada orang-orang yang sholeh pada apa-apa yang telah Engkau membuat rindu padanya". Lalu Nabi Muhammad berkata pada sahabat Anas bin Malik. "Wahai Anas, pergilah dan katakan padanya "mintakanlah ampunan Allah untuk untukku". Lalu Sahabat Anas bergegas dan menyampaikan pada diperintahkan oleh Nabi Muhammad. Orang asing itupun bertanya "Apakah kamu utusannya utusan Allah (disuruh oleh Nabi Muhammad). Sahabat Anas menjawab "Ya betul (saya disuruh oleh Rasulullah)". Orang asing itupun lalu berkata "Sampaikan pada Rosulullah Bahwa Allah telah memulyakan kamu (Nabi Muhammad) atas seluruh para Nabi, sebagaimana Allah telah memuliakan bulan Ramadlan atas bulan-bulan yang lain, dan Allah telah memuliakan umat kamu (Nabi Muhammad) atas seluruh umat yang lain, sebagaimana Allah telah memuliakan hari Jum'at daripada hari yang lain". Sejenak kemudian, para sahabat melihat pria asing tersebut bergegas pergi, (dan Nabi Muhammad memberitahu bahwa pria asing) tadi adalah Nabi Khidir ${ }^{10}$.

10 Imam al-Baihaqi. Dalail an-Nubuwwah. Maktabah Syamilah (Kitab Digital). Juz 5 hal 423. 
Mengomentari hadits ini, banyak ulama' menganggap bahwa hadits ini adalah hadits dho'if, karena ada perawi Katsir bin Abdillah. Namun demikian, hadits ini diriwayatkan oleh perawi-perawi yang lain karena hadits sejenisnya juga telah ditakhrij oleh Abu Jakfar Ahmad, Ibn Asakir dari Jalur Muhammad bin Fadl bin Jabir dan lainnya11.

Selain itu banyak kisah yang diriwayatkan oleh para sahabat bahwa Nabi Khidir hadir di tengah-tengah para sahabat (bersama Nabi Muhammad). Bahkan saat Nabi Muhammad wafat, Nabi Khidir hadir untuk melakukan takziyah, dan Sayyidina Alilah yang mengenali dan menemuinya ${ }^{12}$.

Dalam era modern saat ini, banyak kesaksian yang menyatakan bahwa Nabi Khidir masih hidup hingga saat ini. Kesaksian-kesaksian tersebut diberikan oleh orang-orang diakui kesholehannya. Salah satu kisah tersebut dapat dijumpai dalam Kisah Nabi Khidir dan Syaichona Moh. Cholil Bangkalan dengan Hadrotus Syaikh Kiai Hasyim Asy'ari. Pada suatu ketika, berlangsung hujan deras di sekitar Bangkalan, sementara di luar pondok Demangan ada seorang kakek tua renta, lusuh, dan tidak mempu berjalan. Syaichona Cholil Bangkalan keluar dari rumah seraya bertanya pada para santri "Wahai para santri, adakah di antara kalian yang mau menggendong tamuku di luar sana itu?" Syaichona Kholil Bangkalan bertanya kepada para santrinya. Lalu Hasyim Asy'ari maju menjawab pertanyaan sang Guru. "Saya siap, Kiai". Hasyim Asy'ari mengiyakan saja perintah sang Guru tanpa memedulikan kondisi hujan deras yang ada. Hasyim Asy'ari lalu muda menggendong tamunya ini dengan penuh ketulusan dan mengantarkannya ke kediaman Syaichona Moh. Cholil Bangkalan. Anehnya, Syaichona Moh. Cholil Bangkalan menerima sang tamu dengan penuh ta'dhim. Keduanya kemudian masuk ruang tamu khusus dan berdialog empat mata.

11 Syihabuddin Ibn Hajar al-Asqolani. Az-Zahr al-Nadhor fi Akhbari al-Khidr. Maktabah Syamilah. Juz 1 hal 95.

12 Ibid. Syihabuddin Ibn Hajar al-Asqolani. Maktabah Syamilah. Juz 1 hal 115. Lihat juga, Ahmad bin Abi Bakr al-Bushiri. Ittihaf al-Khoiroh al-Mahroh. Maktabah Syamilah. Juz 2 hal 526. 
Saat berselang lama kemudian, Syaichona Moh. Cholil Bangkalan keluar dan kembali memanggil santri. "Wahai para santri, siapa para santri yang mau membantu tamu ini pulang? Kiai Hasyim Asy'ari kembali menyahut menyatakan siapa menerima perintah sang Guru. "Saya selalu siap, Kiai,". Sejenak kemudian, tamu kakek tua itupun, diantarkan sampai keluar pesantren dengan kehati-hatian, sesuai yang diperintahkan sang Kiai. Kemudian Hasyim kembali ke pesantren dan melaporkan tugasnya selesai. Sekembalinya ke pondok, Syaichona Moh. Cholil Bangkalan berkata. "Santri-santriku, saksikanlah bahwa ilmuku telah dibawa santri itu," tegas Syaichona Moh. Cholil sambil menunjuk kepada sosok Hasyim muda yang luar biasa itu. Syaichona Moh. Cholil kemudian menjelaskan bahwa tamu orang tua yang baru saja datang adalah Nabi Khidir. Para santri tidak menyangka, dan Hasyim Asy'arilah yang kemudian mendapatkan kesempatan luar biasa karena melayani Nabi Khidir seorang kekasih Allah, yang penuh misterius ${ }^{13}$.

\section{Kisah Nabi Khidir dan Nabi Musa}

Kisah Nabi Khidir dan Nabi Musa diabadikan dalam al-Qur'an. Kisah ini sangat masyhur dan diabadikan dalam al-Qur'an surat al-Anbiya' dan al-Kahfi. Kisah Nabi Khidir dan Nabi Musa diawali dari sebuah kisah "kekhilafan" Nabi Musa yang merasa bahwa beliau adalah manusia paling pintar/alim yang ada di dunia. Nabi Musa merasa bahwa derajat kenabian yang disandangnya mencukupkan status bahwa beliaulah manusia yang paling tinggi derajatnya.

Dalam satu kesempatan beliau berdakwah kepada kaum Bani Israil. Selesai berdakwah, salah seorang kaum Bani Israil bertanya pada Nabi Musa. "Apakah ada orang yang lebih 'alim selain Engkau?" Nabi Musa menjawab tidak ada orang yang lebih alim (lagi) daripada saya. Lalu Allah menegur Nabi Musa dan menyebutkan bahwa (masih) ada hambanya yang lebih alim daripada Nabi Musa yang menetap di Majma' al-Bahrain (pertemuan dua laut). Nabi Musa lalu bertanya "Bagaimana saya (bisa menemui dan belajar) denganya? Allah lalu memberikan cara untuk

13 https://bangkitmedia.com/bertemu-nabi-khidir-syaikhona-kholil-didik-kiaihasyim-asyari/. Diakses pada 26 Maret 2109. 
(menemui dan belajar) kepadanya "Ambillah ikan dan jadikanlah sebagai (tanda-tanda dalam solusi) permasalahan.

Kisah ini didasarkan pada sebuah hadits ${ }^{14}$.

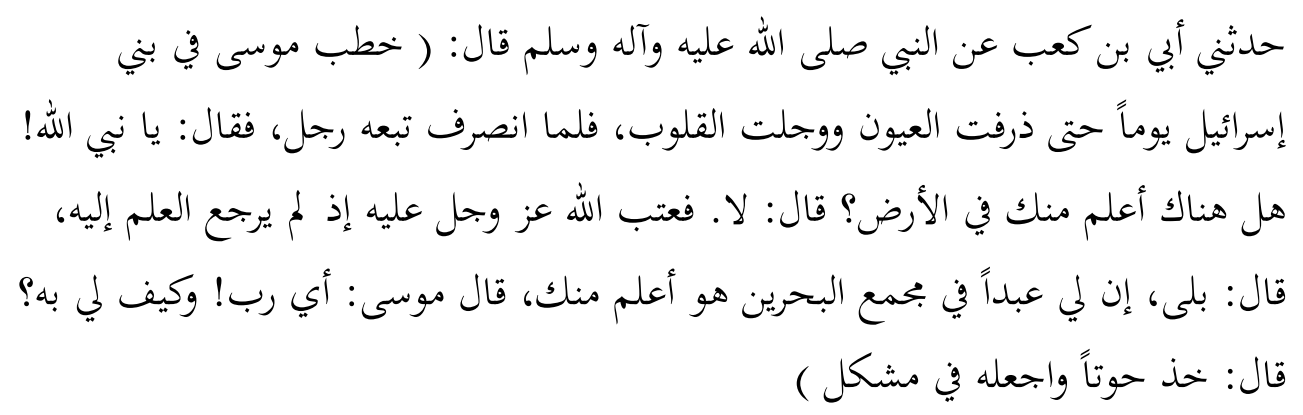

Sesuai dengan perintah yang Allah berikan, lalu Nabi Musa mengajak salah seorang muridnya berangkat menemui Nabi Khidir. Beliau berdua lalu berangkat menempuh perjalanan dengan membawa bekal ikan. Sesampainya pada sebuah bukit, Nabi Musa berhenti beristirahat dan berbincang-bincang dengan muridnya "Saya tidak ingin membebanimu (dengan mengikuti perjalananku), seandainya Allah menghidupkan ikan yang sudah mati (sebagai tanda-tanda bertemu dengan Nabi Khidir)". Sang murid menjawab "Engkau tidak membebani (saya tidak merasa terbeban mengikutimu)". Tak lama kemudian, Ikan yang dibawa lalu hidup. Sejenak kemudian Nabi Musa lalu tertidur. Saat terbangun, Nabi Musa langsung melanjutkan perjalanan sementara sang murid memberitahukan perihal ikan yang kembali hidup.

Perjalananpun berlangsung siang dan malam, hingga saat terasa letih, Nabi Musa berhenti.

آتِنَا غَدَاءَنَا لَقَدْ لَقِينَا مِنْ سَفَرِنَا هَذَا نَصَبًا

Bawalah ke mari makanan kita. Sesungguhnya kita telah merasa letih karena perjalanan kita ini.' (QS. Al-Kahfi: 62)

${ }^{14}$ Abu Ishaq al-Huwaini. Qishshotu Musa wa al-Khidr. Maktabah Syamilah. Juz 1 hal 2. 
Lalu sang muridpun teringat "ikan (yang telah digoreng itu telah hidup) dan melompat ke dalam air". Lalu Nabi Musa berkata:

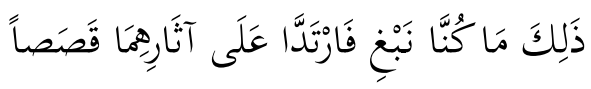

Itulah tempat yang kita cari,' lalu keduanya kembali mengikuti jejak mereka semula.' (QS. Al-Kahfi: 64)

Nabi Musa dan muridnya pun bergegas kembali menyusuri perjalanan yang telah dilalui. Setibanya mereka di batu tersebut, mereka mendapati seorang lelaki yang tertutup kain berwarna hijau, yang terselempang dari bahu kepala hingga kaki, lalu Musa memberi salam kepadanya.

Khidir (orang itu) bertanya, 'Apakah di tanahku ada salam?' Musa menjawab, 'Aku adalah Musa.' Khidir bertanya, 'Musa yang dari Bani Israil?' Musa menjawab, 'Benar!'

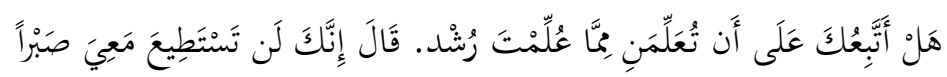

"Bolehkah aku mengikutimu supaya kamu mengajarkan kepadaku ilmu yang benar di antara ilmu-ilmu yang telah diajarkan kepadamu?' Dia menjawab, 'Sesungguhnya kamu sekali-kali tidak akan sanggup sabar bersamaku." (QS. Al-Kahfi: 67)

Khidir berkata, 'Wahai Musa, aku ini mengetahui suatu ilmu dari Allah yang hanya Dia ajarkan kepadaku saja. Kamu tidak mengetahuinya. Sedangkan engkau juga mempunyai ilmu yang hanya diajarkan Allah kepadamu saja, yang aku tidak mengetahuinya.' Musa berkata:

$$
\text { سَتَجِدُدِين إِن شَاء اللَّهُ صَابِراً وَلَا أَعْعِي لَكَ أَمْراً }
$$

'Insya Allah, kamu akan mendapati aku sebagai seorang yang sabar dan aku tidak akan menentangmu dalam suatu urusan pun.' (QS. Al-Kahfi: 69) 
Kemudian, keduanya berjalan di tepi laut. Tiba-tiba lewat sebuah perahu. Mereka berbincang-bincang dengan para penumpang kapal tersebut agar berkenan membawa serta mereka. Akhirnya, mereka mengenali Khidhir, lalu penumpang kapal itu membawa keduanya tanpa diminta upah.

Tiba-tiba, seekor burung hinggap di tepi perahu itu, ia mematuk (meminum) seteguk atau dua kali teguk air laut. Kemudian, Khidhir memberitahu Musa, 'Wahai Musa, ilmuku dan ilmumu tidak sebanding dengan ilmu Allah, kecuali seperti paruh burung yang meminum air laut tadi!'

\section{Ilmu Nabi Khidir yang diajarkan kepada Nabi Musa}

\section{Merusak perahu}

Khidhir lalu menuju salah satu papan perahu, kemudian Khidhir melubanginya. Melihat kejanggalan ini Musa bertanya, ‘Penumpang kapal ini telah bersedia membawa serta kita tanpa memungut upah, tetapi mengapa engkau sengaja melubangi kapal mereka? Apakah engkau lakukan itu dengan maksud menenggelamkan penumpangnya?' Khidhir menjawab:
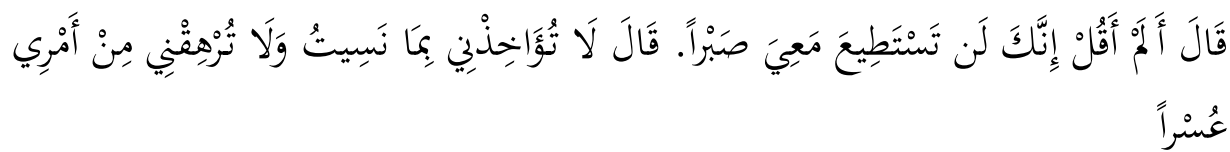

'Bukankah aku telah berkata, 'Sesungguhnya kamu sekali-kali tidak akan sabar bersamaku.' Musa berkata, 'Janganlah kamu menghukum aku karena kelupaanku." (QS. Al-Kahfi: 72-73)

Itulah sesuatu yang pertama kali dilupakan Musa, kemudian keduanya melanjutkan perjalanan.

\section{Membunuh anak kecil}

Keduanya bertemu dengan seorang anak laki-laki sedang bermain bersama kawan-kawannya. Tiba-tiba Khidhir menarik rambut anak itu dan membunuhnya. Melihat kejadian aneh ini, Musa bertanya:

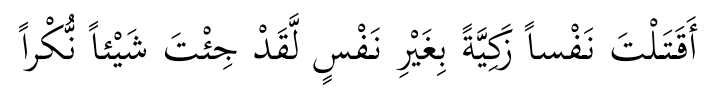


'Mengapa kamu membunuh jiwa yang bersih, bukan karena dia membunuh orang lain? Sesungguhnya kamu telah melakukan sesuatu yang mungkar.' (QS. Al-Kahfi: 74)

Khidhir menjawab:

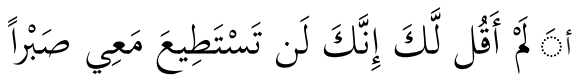

'Bukankah sudah aku katakan kepadamu bahwa sesungguhnya kamu tidak akan dapat sabar bersamaku?' (QS. Al-Kahfi: 75).

\section{Membangun rumah tanpa upah}

Nabi Musa dan Nabi Khidir lalu melanjutkan perjalanan. Hingga tatkala keduanya sampai kepada penduduk suatu negeri, mereka minta dijamu kepada penduduk negeri itu, tetapi penduduk negeri itu tidak mau menjamu mereka. Kemudian keduanya mendapatkan dalam negeri itu dinding rumah yang hampir roboh.

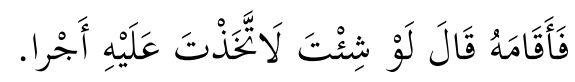

Khidhir berkata bahwa, melalui tangannya, dia menegakkan dinding itu. Musa berkata, 'Jikalau kamu mau, niscaya kamu mengambil upah untuk itu

\section{Penjelasan atas (Anggapan) Kontroversi Perbuatan Nabi Khidir}

Pada prinsipnya, apa yang dinilai kontroversi oleh Nabi Musa, Nabi Khidir telah menjelaskan maksud dan tujuan dibalik perbuatan-perbuatan yang dinilai kontroversi. Penjelasan perbuatan yang dianggap kontroversi tersebut dilakukan setelah kejadian peristiwa yang ketiga. Nabi Khidir berkata yang diabadikan dalam al-Qurán:

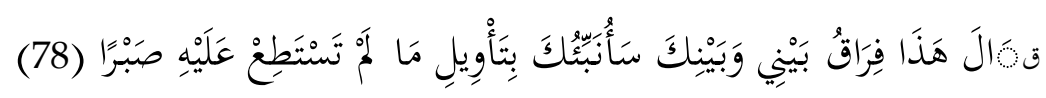

"Khidir berkata. "Inilah (saatnya) perpisahan antara aku dan kamu, akan aku beritahukan kepadamu tujuan-tujuan perbuatan-perbuatan yang kamu tidak dapat sabar terhadapnya"". 


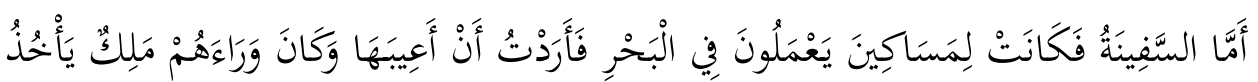 \\ كُولَّ سَفِيَنَة غَصْبًَا (79)}

"Adapunn bahtera itu adalah kepunyaan orang-orang miskin yang bekerja di laut, dan aku bertujuan merusakkan bahtera itu, karena di hadapan mereka ada seorang raja yang merampas tiap-tiap bahtera".

Dalam kitab Tafsir al-Qurtubiy disebutkan bahwa bahtera (kapal) ini dimiliki oleh sepuluh orang bersaudara, yang telah ditinggal mati oleh orang tuanya. Dan kapal tersebut adalah peninggalan dari orangtuanya. Lima orang normal dan bisa bekerja, sementara lima orang saudara lainnya adalah buta, tuli, bisu, lumpuh dan gila ${ }^{15}$.

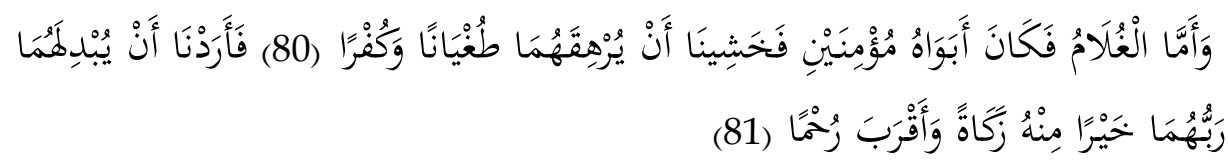

"Dan adapun anak muda itu, maka kedua orangtuanya adalah orangorang mukmin, dan kami khawatir bahwa dia akan mendorong keduaorangtuanya itu kepada kesesatan dan kekafiran. Dan Kami menghendaki, supaya Tuhan mereka mengganti bagi mereka dengan anak lain yang lebih baik kesuciannya dari anaknya itu dan lebih dalam kasih sayangnya (kepada kedua orangtuanya)".

Ada dua pendapat tentang kondisi anak muda yang dibunuh oleh Nabi Khidir. Pertama, bahwa sang anak muda tersebut adalah anak muda yang nakal, menjadi pembegal dan suka berbuat kejahatan. Kedua. Anak tersebut adalah anak yang baik, Namun (dalam pengetahuan Allah) sang anak tersebut kelak sesudah dewasa akan mejerumuskan kedua orangtuanya dalam kekafiran (dan Allah mewahyukan kepada Nabi Khidir untuk membunuhnya) ${ }^{16}$. Namun Ibn Abbas bahkan meriwayatkan bahwa anak tersebut telah kafiri ${ }^{17}$.

15 Muhammad bin Ahmad al-Qurtubiy. Tafsir al-Qurtubiy. Maktabah Syamilah. Juz 11 Hal 33.

16 Nisabur. Tafsir an-Nisaburiy. Maktabah Syamilah. Juz 05 Hal 202.

17 Ibid. Muhammad bin Ahmad al-Qurtubiy. Tafsir al-Qurtubiy. Maktabah Syamilah. Juz 11 Hal 21. 


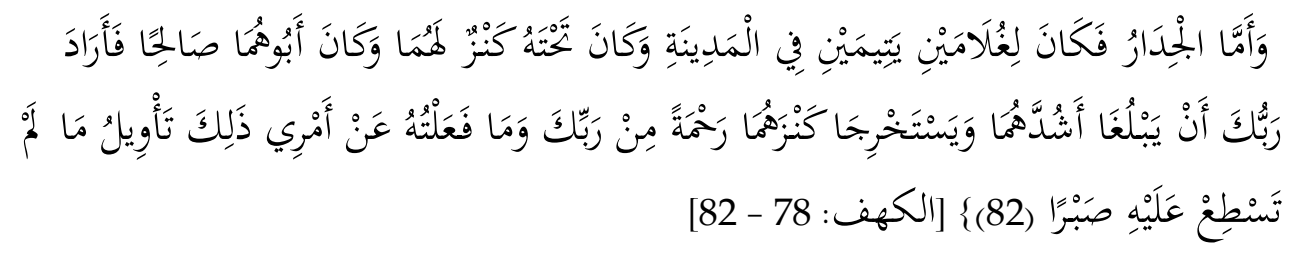

"Adapun dinding rumah adalah kepunyaan dua orang Arab yatim yang di kota itu, dan dibawahnya ada harta benda simpanan bagi mereka berdua, sedang ayanya adalah orang yang shaleh, maka Tuhanmu menghendaki agar supaya mereka sampai kepada kedewasaannya, dan mengeluarkan simpanannya itu, sebagai rahmat dari Tuhanmu, dan bukanlah aku melakukan menurut kemauanku sendiri. Demikian itu adalah tujuan perbuatan-perbuatan yang kamu tidak dapat sabar terhadapnya".

Dalam kaitan dengan ilmu syari'at ${ }^{18}$, tarikat ${ }^{19}$, hakikat ${ }^{20}$, dan makrifat ${ }^{21}$, Muhammad al-Ghozali menulis bahwa seorang alim harus tahu bahwa ilmu terbagi menjadi tiga. Pertama. Ilmu dhohir (luar), yaitu ilmu yang diberikan oleh Allah kepada orang yang kemampuan ada pada batas dhohir (luaran). Kedua; ilmu bathin (dalam) yaitu ilmu yang diberikan oleh Allah kepada orang yang mempunyai kemampuan bathin (dalam) dan ketiga yaitu ilmu yang hanya Allah yang tahu22. Selanjutnya, dalam konteks ilmu hakikat, Ibn Aroby menyitir apa yang pernah disampaikan oleh Imam Junaid bahwa seseorang tidak akan sampai pada derajat hakikat, sampai ada seribu orang yang mengatakan bahwa dia telah menjadi zindiq. Lebih lanjut Ibn Aroby menyebut bahwa Allah telah memberikan pemahaman

18 Syari'at adalah segala sesuatu yang telah Allah perintahkan baik secara langsung (wahyu) maupun melalui nabi-Nya.

19 tarekat adalah jalan khusus bagi salik (penempuh jalan ruhani) untuk mencapai kesempurnaan tauhid, yaitu ma'rifatullah.

20 Hakekat adalah kemampuan seseorang dalam merasakan dan melihat kehadiran Allah di dalam syari'at. Hakekat juga dapat diartikan sebagai sebuah afirmasi akan eksistensi wujud baik yang diperoleh melalui penyingkapam dan penglihatan langsung pada substansinya, atau juga dengan mengalami kondisi-kondisi spiritual, atau mengafirmasi akan ketunggalan Tuhan.

${ }^{21}$ Makrifat diartikan sebagai ilmu yang tidak menerima keraguan atau pengetahuan

${ }^{22}$ Abu Hamid al-Gozali. Ihya' Ulumiddin. Maktabah Syamilah. Juz 1 Hal 106. 
dan pengetahuan kepada Nabi Khidir dan tidak memberikannya kepada Nabi Musa. Demikian juga, Allah memberikan pemahaman dan pengetahuan kepada Nabi Musa namun tidak memberikannya kepada Nabi Khidir. Sehingga pengetahuan Nabi Khidir dan Nabi Musa berbeda. Demikian juga, status keduanya juga berbeda. Pengetahuan dan pemahaman Nabi Khidir berada dalam status 'suprarsional' (sehingga tidak boleh ditentang) sementara pengetahuan dan pemahaman Nabi Musa berada dalam status 'rasional', sehingga memungkinkan adanya ruang diskusi dan penentangan ${ }^{23}$.

\section{Kontroversi Pemikiran dan Perbuatan Gus Dur dalam Perspektif Ilmu Khidir}

Dalam perjalanan sejarah, kontroversi Gus Dur tentang keinginannya mencabut TAP MPR Nomor XXV Tahun 1966 telah dijelaskan dan dikonfirmasi oleh Gus Dur. Hal ini terjadi pada sebuah acara Kick Andy, acara Talk Show yang tayang di TV Swasta Metro TV. Secara singkat, sederhana dan padat dalam acara tersebut, Gus Dur menjawab alasan mengapa dirinya berkeinginan mencabut TAP MPR nomor XXV tahun 1966 tersebut. Alasan-alasan yang keluar dari Gus Dur adalah:

1. Peran dan tanggungjawab antara pemerintah dan masyarakat

a. Menurut Gus Dur, bahwa tugas mengucilkan PKI bukanlah tugas negara, bahwa negara telah memisahkan peran negara dan agama.

b. Peran dan tanggungjawab antara pemerintah dan masyarakat samasama penting. Bahwa yang bertugas untuk menjalankan, tidak hanya terletak pada peran dan tanggungjawab pemerintah saja. Masyarakat juga mempunyai peran dan tanggungjawab terhadap negara. Dalam konteks aliran/gerakan/pemikiran komunis ini, Gus Dur menyebut bahwa masyarakat mempunyai dan tanggungjawab di bidang pengawasan.

2. Bertentangan dengan konsitusi dan undang-undang

Alasan atas dasar konstitusi dan Undang-Undang Dasar disebut Gus Dur berhubungan dengan perlindungan dan jaminan negara terhadap

23 Muhammad bin Abdullah abu Bakar Ibn Ibn Aroby. Al-Futuhat al-Makkiyah. Maktabah Syamilah. Juz 213. 
seluruh rakyat. Bahwa Indonesia telah menjalankan filsafat Pancasila selama berabad-abad, kalaupun tanpa nama.

3. Tidak perlu takut akan kebangkitan PKI

Menurut Gus Dur, bahwa tidak perlu takut terhadap kebangkitan PKI, karena PKI tidak perlu ditakuti.

Menggunakan perspektif ilmu Nabi Khidir, tiga alasan yang telah diklarifikasi sendiri oleh Gus Dur dapat dibaca sebagai pengetahuan yang telah diketahui oleh Gus Dur sesuai dengan kenyataan yang ada. Dalam konteks ilmu hakikat, pengetahuan yang sesuai dengan kenyataan, Gus Dur mengetahui bahwa konstitusi negara telah memberikan jaminan dan perlindungan kepada segenap warga negara tanpa pandang bulu, termasuk di dalamnya perlindungan terhadap paham komunis. Analogi sederhana, pada prinsipnya, sebelum TAP MPR XXV Tahun 1966 itu lahir, keberadaan komunis telah diakui dan dijamin oleh undang-undang dan Pancasila, sehingga komunis dan PKI ada di Indonesia. TAP MPR XXV Tahun 1966 tersebut lahir setelah adanya pemberontakan yang dilakukan oleh PKI. Sebagai pertanyaan, apakah sebuah pelanggaran yang dilakukan oleh seseorang/paham lantas harus melahirkan larangan? Terkait dengan ideologi 'atheis' anti tuhan, anti agama yang diusung oleh komunis, maka Gus Dur menjawabnya dengan keharusan keterlibatan dari seluruh anggota masyarakat dan segenap bangsa untuk mengawasinya. Gus Dur menegaskan bahwa yang bertanggungjawab untuk mengucilkan komunis dan PKI bukanlah tanggung jawab negara, namun menjadi tanggung jawab masyarakat untuk mengucilkan. Dengan kondisi seluruh bangsa berkeyakinan atas sila pertama yang "Ketuhanan Yang Maha Esa", maka dengan sendirinya, ideologi komunis tidak akan diterima oleh seluruh Bangsa Indonesia. Harus diakui bahwa ideologi bertentangan dengan Pancasila dan segenap seluruh bangsa dan warga Negara Indonesia. Namun, menurut Gus Dur, bahwa penentangan terhadap ideologi komunis tidak harus dilakukan oleh negara, namun cukup dilakukan oleh seluruh anggota masyarakat dan seluruh Bangsa Indonesia. Sebagai sebuah analogi pengandaian, jika seluruh bangsa yakin atas sila pertama "Ketuhanan Yang Maha Esa" maka dengan sendirinya Bangsa Indonesia tidak akan menerima atas ideologi komunis, sehingga jika ada 'oknum' 
warga atau masyarakat yang tertarik dengan ideologi komunis, maka pada dasarnya 'oknum' tersebut tidak yakin atas sila pertama 'Ketuhanan Yang Maha Esa'. Inilah maksud jawaban Gus Dur atas peran dan tanggung jawab masyarakat dalam mengucilkan ideologi komunis.

Sebagai tambahan, seorang muslim yang berpegang teguh terhadap ikrar syahadatnya, 'bahwa tidak ada Tuhan selain Allah' tentu telah berikrar bahwa tidak ada sesuatu apapun yang ditakutinya kecuali Allah24. Dengan demikian, menurut Gus Dur, seorang muslim yang yakin atas ikrar syahadatnya, tentu tidak akan takut kepada apapun, termasuk kepada komunis dan PKI, karena yang ditakutinya hanyalah Allah semata.

Diakui atau tidak, pengalaman Gus Dur yang begitu luas, telah menjadikan sosok Gus Dur sebagai pemikir yang matang, berwawasan luas, bahkan mampu melampaui pemikiran pada zamannya. Seperti diibaratkan oleh Yenni Wahid, putri tertua Gus Dur, yang menganalogikan Gus Dur sebagai lokomotif Jepang yang modern dan canggih, sementara rel dan stasiunnya masih kelas Argo ${ }^{25}$. Membenarkan analogi yang diberikan oleh Yenni Wahid, pemikiran Gus Dur yang dianggap kontroversi, pada dasarnya, hanya terletak pada luas jangkauan dan kedalaman pemikiran Gus Dur. Gus Dur mengeluarkan sebuah pemikiran dan berbuat tentu atas dasar pengetahuan dan bacaan Gus Dur yang sangat luas dan dalam. Sementara orang-orang sekitar, belum mampu menjangkau dan belum memahaminya saja. Hal ini, mirip dengan apa yang terjadi dalam dialog Nabi Khidir dan Nabi Musa. Nabi Khidir mengetahui sesuatu yang tidak diketahui oleh Nabi Musa. Dalam bahasa yang lebih sederhana, ilmu Nabi Khidir sudah mencapai level pengetahuan hakikat (dan juga makrifat), sementara ilmu Nabi Musa masih berada di level pengetahuan syari'at. Demikian juga, Gus Dur telah mencapai level pengetahuan hakikat (dan juga makrifat), sementara kebanyakan Bangsa Indonesia masih berada di level syari'at.

${ }^{24}$ Dalam banyak penjelasan, makna dari ikrar syahadat adalah لا معبود بحق إلا اله , bahwa yang pantas disembah hanyalah Allah semata. Demikian, yang pantas ditakuti hanyalah Allah semata. Baca Jalaluddin al-Mahalli dan Jalaluddin as-Suyuthi. Tafsir Jalalain. Maktabah Syamilah. Juz 1 hal 261.

25 Pernyataan Yenni Wahid dalam acara Kick Andy, acara Talk Show yang tayang di TV Swasta Metro TV. 


\section{Kesimpulan}

Gus Dur adalah salah satu pemikir bangsa yang langka. Pemikirannya tidak hanya luas dan dalam, namun juga lintas zaman dan waktu. Kedalaman dan keluasan wawasan pemikiran Gus Dur mampu menembus cakrawala pemikiran di masa depan. Terbukti, pemikiran yang dianggap kontroversi justru menemukan momentumnya setelah Gus Dur berpulang dan tiada. Dalam cakrawala pemikiran, Gus Dur pada dasarnya 'hanya' menyampaikan pengetahuan yang diketahui dan orang lain belum mengetahuinya. Demikian juga, Nabi Khidir saat 'memberi pelajaran' pada Nabi Musa. Nabi Khidir 'hanya' menyampaikan apa yang diketahui sementara Nabi Musa belum mengetahuinya. Gus Dur mengeluarkan sebuah pemikiran dan berbuat, tentu atas dasar pengetahuan dan bacaan Gus Dur yang sangat luas dan dalam. Sementara orang-orang sekitar, belum mampu menjangkau dan belum memahaminya saja. Hal ini, mirip dengan apa yang terjadi dalam dialog Nabi Khidir dan Nabi Musa. Nabi Khidir mengetahui sesuatu yang tidak diketahui oleh Nabi Musa. Dalam bahasa yang lebih sederhana, ilmu Nabi Khidir sudah mencapai level pengetahuan hakikat (dan juga makrifat), sementara ilmu Nabi Musa masih berada di level pengetahuan Syari'at. Demikian juga, Gus Dur telah mencapai level pengetahuan hakikat (dan juga makrifat), sementara kebanyakan Bangsa Indonesia masih berada di level syari'at. 


\section{DAFTAR PUSTAKA}

Aroby, Muhammad bin Abdullah abu Bakar Ibn. Al-Futuhat al-Makkiyah. Maktabah Syamilah. Juz $1 \mathrm{Hal} 213$.

Asqolani, Syihabuddin Ibn Hajar al-. Az-Zahr al-Nadhor fi Akhbari al-Khidr. Maktabah Syamilah.

Baihaqi, Imam al-. Dalail an-Nubuwwah. Maktabah Syamilah (Kitab Digital).

Barton, Greg. Biografi Gus Dur The Autorized Biography Of Abdurrahman Wahid. Yogyakarta: LKiS. Cet VIII. 2008.

Bushiri, Ahmad bin Abi Bakr al-. Ittihaf al-Khoiroh al-Mahroh. Maktabah Syamilah.

Gozali, Abu Hamid al-. Ihya' Ulumiddin. Maktabah Syamilah. Juz 1 Hal 106.

https:// bangkitmedia.com/ bertemu-nabi-khidir-syaikhona-kholil-didikkiai-hasyim-asyari/. Diakses pada 26 Maret 2109.

Huwaini, Abu Ishaq al-. Qishshotu Musa wa al-Khidr. Maktabah Syamilah.

Jalaluddin, al-Mahalli dan as-Suyuthi. Tafsir Jalalain. Maktabah Syamilah.

Kaelan, MS. 2014. Pendidikan Pancasila. Yogyakarta: Paradigma. Cet X 2014.

Nisabur. Tafsir an-Nisaburiy. Maktabah Syamilah.

Qurtubiy, Muhammad bin Ahmad al-. Tafsir al-Qurtubiy. Maktabah Syamilah.

TAP MPR No XXV Tahun 1966 tentang Pembubaran Partai Komunis Indonesia, pernyataan sebagai organisasi terlarang di seluruh wilayah negara Republik Indonesia bagi Partai Komunis Indonesia dan larangan setiap kegiatan untuk menyebarkan atau mengembangkan faham atau ajaran Komunisme/MarxismeLeninisme. 